\title{
The importance of the peritoneal dialysis catheter material in order to perform optimum dialysis in veterinary medicine
}

\author{
DOI: $10.35530 / I T .071 .06 .1843$
}

\section{ABSTRACT - REZUMAT}

\section{The importance of the peritoneal dialysis catheter material in order to perform optimum dialysis in veterinary medicine}

This study was conducted on 44 dogs, aged between 10 months and 15 years, weighing between 0.9 and 8.5 kilograms, during 72 months. We created four batches of 11 dogs each. First batch received silicone peritoneal catheters with two Dacron cuffs, second batch received silicone peritoneal catheters without Dacron cuffs, third batch received polypropylene peritoneal catheters with two Dacron cuffs and fourth batch received polypropylene peritoneal catheters without Dacron cuffs. All the dogs were treated with the same peritoneal dialysis solution, at the same interval, in the same doses and at the same temperature and all the peritoneal catheters were straight Blake. In dogs from the first batch, we experienced minimum subcutaneous leaks of peritoneal dialysis solution and the catheters were permeable for at least 90 days. In the second batch, we experienced constant and reduced subcutaneous leaks of peritoneal dialysis solution and the catheters were permeable for at least 90 days. In the third batch, we experienced medium subcutaneous leaks of peritoneal dialysis solution and the catheters were permeable for at least 45 days. In the fourth batch, we experienced important subcutaneous leaks of peritoneal dialysis solution and the catheters were permeable for at most 15 days. The study conclusion is that the best peritoneal catheter it is represented by the silicone peritoneal catheters with two Dacron cuffs.

Keywords: peritoneal, dialysis, catheter, veterinary

\section{Importanța materialului cateterului de dializă peritoneală pentru efectuarea dializei optime}

\section{în medicina veterinară}

Acest studiu a fost realizat pe 44 de câini, cu vârste cuprinse între 10 luni și 15 ani, cu o greutate cuprinsă între 0,9 și 8,5 kilograme, pe parcursul a 72 de luni. S-au creat patru loturi a câte 11 câini fiecare. Primul lot a fost tratat utilizând catetere peritoneale din silicon cu două manșete de Dacron, al doilea lot a fost tratat utilizând catetere peritoneale din silicon fără manșete de Dacron, al treilea lot a fost tratat utilizând catetere peritoneale din polipropilenă cu două manșete de Dacron și al patrulea lot a fost tratat utilizând catetere peritoneale din polipropilenă fără manșete de Dacron. Toți câinii au fost tratați cu aceeași soluție de dializă peritoneală, la același interval, în aceleași doze și la aceeași temperatură, iar toate cateterele peritoneale au fost de tip Blake drept. La câinii din primul lot, s-au observat scurgeri minime subcutanate de soluție de dializă peritoneală, iar cateterele au fost permeabile timp de cel puțin 90 de zile. La al doilea lot, s-au observat scurgeri subcutanate constante și reduse de soluție de dializă peritoneală, iar cateterele au fost permeabile timp de cel puțin 90 de zile. La al treilea lot, s-au observat scurgeri subcutanate medii de soluție de dializă peritoneală, iar cateterele au fost permeabile timp de cel puțin 45 de zile. La al patrulea lot, s-au observat scurgeri subcutanate semnificative de soluție de dializă peritoneală, iar cateterele au fost permeabile timp de cel mult 15 zile. Concluzia prezentei lucrări este că, în mare parte, cel mai bun cateter peritoneal este cateterul realizat din silicon cu două manșete de Dacron.

Cuvinte-cheie: peritoneală, dializă, cateter, veterinar

\section{INTRODUCTION}

Dialysis represents the separation process of a colloidal dispersion substance from molecular dispersion particles, based on the property of certain membranes to retain only colloidal particles [1].

Peritoneal dialysis has the main indication in numerous cases of intoxications and metabolic misbalances. It can be also used in order to remove some dialyzable toxins, such as ethylene glycol, barbiturates, ethanol, propoxyphene and hydantoin, and in cases of electrolyte imbalances, the most representative one being hyperkalemia [2].
Patients showing acute nonanuric uremia, with blood urea nitrogen (BUN) over $100 \mathrm{mg} / \mathrm{dl}$ or with creatinine levels higher than $10 \mathrm{mg} / \mathrm{dl}$ can be treated using peritoneal dialysis [3].

Peritoneal dialysis is totally contraindicated in patients with fibrosis or abdominal malignant tumors and peritoneal adhesions [4].

The ideal peritoneal dialysis catheter permits an adequate administration and a complete evacuation of the dialysate, it generates minimum subcutaneous losses, it prevents infection both in the subcutaneous tissue and in the peritoneal cavity [2].

Acute dialysis catheters are placed under local anaesthesia, percutaneously, using a stiletto and 
heparinization is immediately required. The acute dialysis catheters are usually straight and they have multiple orifices at the distal end. Acute dialysis catheters usually have no Dacron cuffs used to protect the patient against bacterial infection and migration of the catheter. That for, their usage may lead to peritonitis in a high rate, in case of extensive use [5]. Chronic peritoneal dialysis catheters have certain models, both extraperitoneal and intraperitoneal, created especially to minimize blockage and to reduce secondary effects. Chronic peritoneal dialysis catheters are made of rubber, silicon or polyurethane [6].

Chronic peritoneal dialysis catheters are designed with one or more Dacron cuffs used to protect the patient against bacterial infection and migration of the catheter. In case of extensive use of catheters without Dacron cuffs, this may lead to a high peritonitis rate. These catheters are placed under general anaesthesia [7].

The peritoneal dialysis catheter is fixed in place, after the placement, by suturing it to the skin with a monofilament non-absorbable thread $4 / 0$ to $2 / 0$ range. Roman sandal suture and the Chinese fingertrap are the two most commonly used sutures [8].

Polypropylene (PP) is the most used monofilament thread for suturing the peritoneal dialysis catheter in place. Polypropylene, also known as polypropene, used in a wide variety of applications, is a thermoplastic polymer. It is produced via chain-growth polymerization from the monomer propylene. Its properties are similar to polyethylene, but it is more heat resistant and slightly harder. Polypropylene is a white, mechanically rugged material with a high chemical resistance. Polypropylene is the secondmost widely produced plastic (after polyethylene) and it is often used in labelling and packaging [2].

In human medicine, once surgically placed, peritoneal dialysis catheters could be used for dialysis after minimum 10 to 14 days [9].

This 10 to 14 days interval allows the wound to heal and to create a scar around the two Dacron cuffs. This will minimize the dialysate leakage around the insert site of the catheter. For medical reasons, in veterinary medicine, peritoneal dialysis starts immediately after the peritoneal dialysis catheters placement. This is done because most of the cases are severe emergencies and cannot be postponed for such a period of time $[10,11]$.

In the present study, we have tested peritoneal dialysis catheters made from silicone with two Dacron cuffs, silicone peritoneal catheters without Dacron cuffs, polypropylene peritoneal catheters with two Dacron cuffs and polypropylene peritoneal catheters without Dacron cuffs.

\section{MATERIALS AND METHODS}

This study was conducted on 44 canine patients with AKI (Acute Kidney Injury), both males and females all of them being treated using peritoneal dialysis. The study was conducted between June 2014 and June 2020. All patients were tested for other associated pathologies and none of the selected patients presented other morbidities of infections of the peritoneal cavity or at the skin, around the catheter placement area.

All dogs enrolled in this study were aged between 10 months and 15 years, weighing between 0.9 and 8.5 kilograms. We created four batches of 11 dogs each. First batch received silicone peritoneal catheters with two Dacron cuffs, second batch received silicone peritoneal catheters without Dacron cuffs, third batch received polypropylene peritoneal catheters with two Dacron cuffs and fourth batch received polypropylene peritoneal catheters without Dacron cuffs.

All canine patients were treated using the same peritoneal dialysis solution, at the same interval, in the same doses and at the same temperature and all the peritoneal catheters were straight Blake.

In all groups, the peritoneal catheters were placed on canine patients being under general anaesthesia and the all the catheters were placed using a surgical procedure. After the catheter placement, the catheters required immediate heparinization. The surgical placement of the catheter is needed in order to inspect the abdominal cavity and for the omentectomy. The omentectomy was also important and it is recommended in order to avoid the catheter blockage by the omentum. In order to reach the bottom of the Douglas pouch, all peritoneal dialysis catheters were cut, using a surgical scissor. In order to do this, the peritoneal catheters were pre-measured and inserted into the peritoneal cavity after being cut. The abdominal cavity was surgically closed with an absorbable monofilament suture material and the last suture, or a separate suture point, was placed through the distal (abdominal) Dacron cuff of the peritoneal catheter, in the catheters with Dacron cuffs and around the catheters in those without Dacron cuffs. After this, the anterior end of the peritoneal catheter was passed under the skin, through a subcutaneous tunnel, on the lateral side and it was exteriorized through the skin, 3-5 cm away from the main incision line. This way, the proximal Dacron cuff was located under the skin in the catheters with two Dacron cuffs.

The peritoneal catheters were sutured at the skin using a $4 / 0$ to $2 / 0$ non-absorbable monofilament suture material, depending on patient size. We placed Roman sandal sutures in all patients.

After the placement of the peritoneal catheters, the surgical wound was dressed using antiseptics and the peritoneal catheters received special catheter bandaging. All patients received a special corset to prevent them to reach the peritoneal catheter and to prevent them from pulling it from the peritoneal cavity. The owners of every canine patient received the same training regarding the catheter handling, patient care and wound dressing.

The first treatments were performed in the Clinic and, after the first 3 days, all canine patients were sent home with specific instructions and training for the owners, the therapy being continued by the owners. 


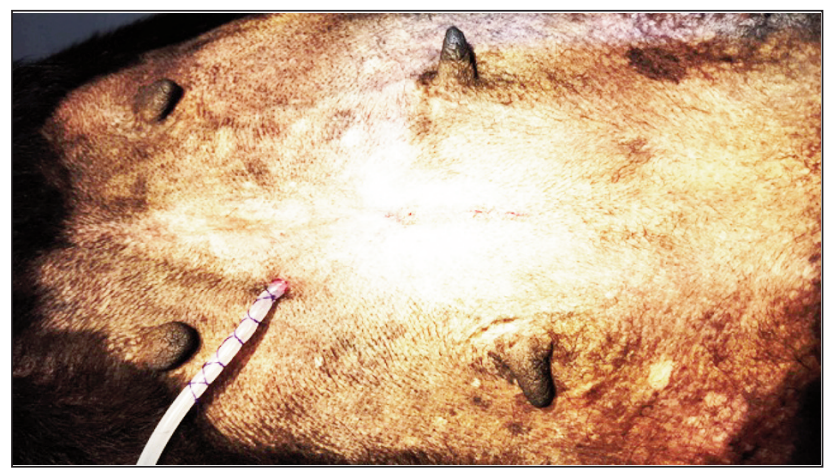

Fig. 1. Placing of the silicone peritoneal catheter with two Dacron cuffs in dogs with AKI

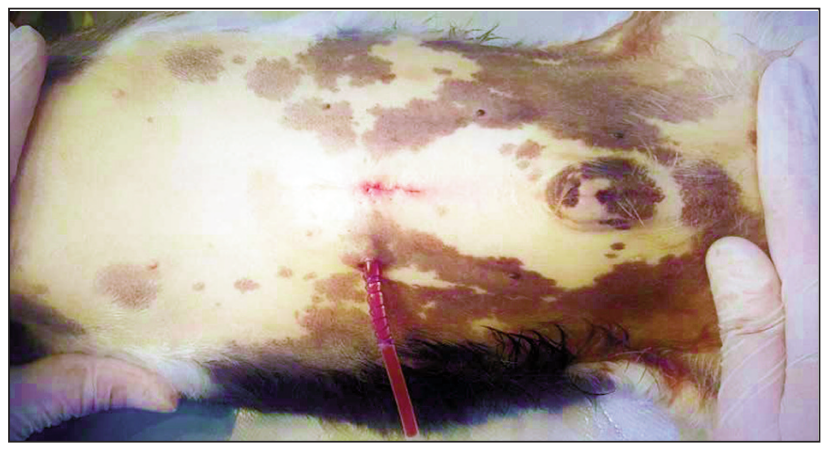

Fig. 2. Placing of the silicone peritoneal catheter without Dacron cuffs in dogs with AKI

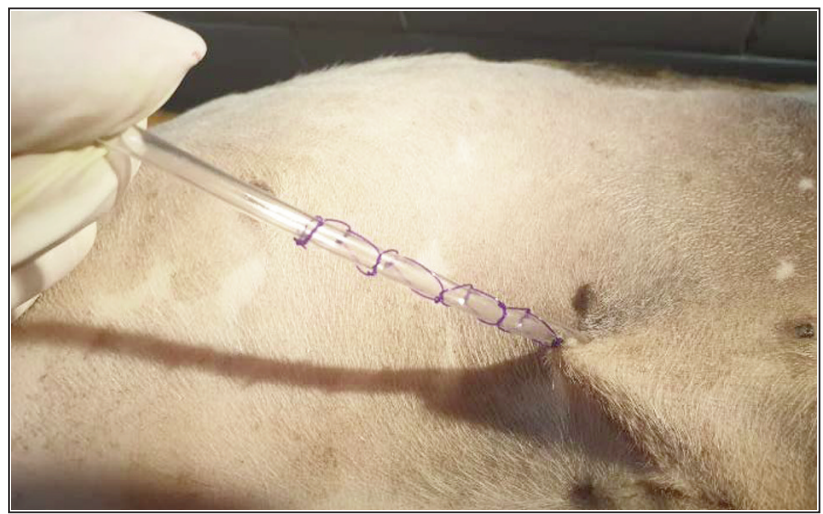

Fig. 3. Placing of the polypropylene peritoneal catheter with two Dacron cuffs in dogs with AKI

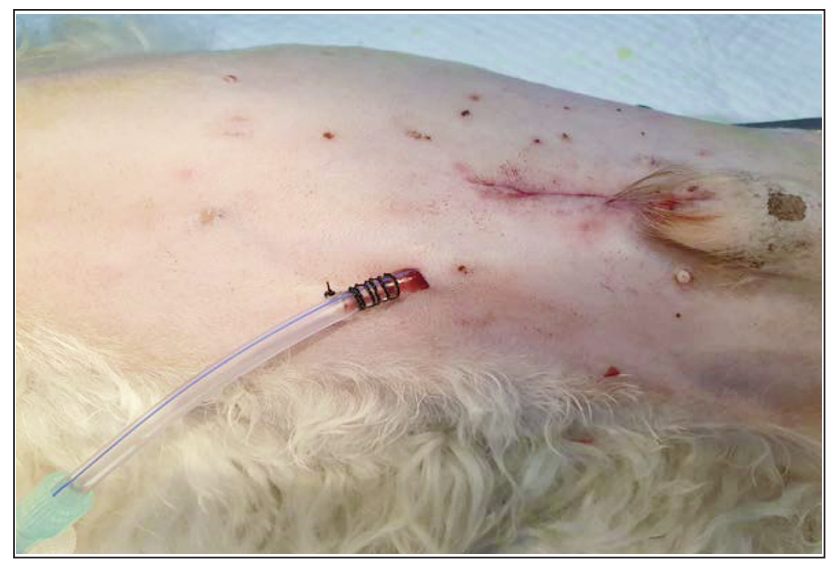

Fig. 4. Placing of the polypropylene peritoneal catheter without Dacron cuffs in dogs with AKI
We have used the same peritoneal dialysis products, from the same pharmaceutical company in all canine patients. The fluid exchanges and all the dwelling times were identical in all canine patients.

\section{RESULTS AND DISCUSSIONS}

Analysing all the recordings from all the canine patients undergoing peritoneal dialysis, we have reached numerous data. All canine patients were carefully followed until they were complete recovered or until the end of treatment (death).

All canine patients from the first group, treated using silicone peritoneal dialysis catheters with two Dacron cuffs and sutured using Roman sandal suture held the catheters in place for at least 90 days (11 out of $11,100 \%$ ) and experienced minimum subcutaneous leaks of peritoneal dialysis solution. The catheters were permeable throughout the entire period.

In the second batch, 10 out of 11 patients $(90.90 \%)$, having placed silicone peritoneal catheters without Dacron cuffs experienced constant and reduced subcutaneous leaks of peritoneal dialysis solution and the catheters were permeable for at least 90 days.

All patients from the third group, having placed polypropylene peritoneal dialysis catheter with two Dacron cuffs and sutured using Roman sandal suture held the catheters in place for at least 45 days (11 out of $11,100 \%$ ) and experienced medium subcutaneous leaks of peritoneal dialysis solution. The catheters were permeable throughout the entire period.

In the fourth batch, 9 out of 11 patients (81.81\%), having placed polypropylene peritoneal catheters without Dacron cuffs experienced constant and important subcutaneous leaks of peritoneal dialysis solution and the catheters were permeable for at least 15 days.

The most important disadvantage of the permanent polypropylene dialysis catheters, comparing to the silicone peritoneal catheters is a shorter working duration for the procedure, which is really important. Also, the importance of the two Dacron cuffs is a major factor in the leakage of the peritoneal dialysis solution.

\section{CONCLUSIONS}

Using silicone dialysis catheters with two Dacron cuffs needs a wider incision for the catheter placement, more labour for the procedure, with higher costs, but is has less risks.

In the present study, all canine patients from the first group, treated using silicone peritoneal dialysis catheters with two Dacron cuffs and sutured using Roman sandal suture held the catheters in place for at least 90 days (11 out of $11,100 \%$ ) and experienced minimum subcutaneous leaks of peritoneal dialysis solution. The catheters were permeable throughout the entire period, this finding being similar with the research of Thornhill J.A. [5].

10 out of 11 patients $(90.90 \%)$, having placed silicone peritoneal catheters without Dacron cuffs experienced constant and reduced subcutaneous leaks of 
peritoneal dialysis solution and the catheters were permeable for at least 90 days, similar with the studies of Viţălaru, B. Al., 2020 [1].

All patients from the third group, having placed polypropylene peritoneal catheter with two Dacron cuffs and sutured using Roman sandal suture held the catheters in place for at least 45 days with medium subcutaneous leaks of peritoneal dialysis solu- tion. The catheters were permeable throughout the entire period.

9 out of 11 patients (81.81\%), having placed polypropylene peritoneal catheters without Dacron cuffs (fourth batch) experienced constant and important subcutaneous leaks of peritoneal dialysis solution and the catheters were permeable for at least 15 days.

\section{REFERENCES}

[1] Viţălaru, B.A., Peritoneal Dialysis in small animals, Ed. Sciendo, Bucharest, 2020

[2] Acierno, M.J., Labato, M., Kidney Diseases and Renal Replacement Therapies, An Issue of Veterinary Clinics: Small Animal Practice, Elsevier-Saunders, Ottawa, 2011

[3] Vițălaru, B.A., Ștefănescu, A., Peritoneal Dialysis in small animals, Ed. Printech, Bucharest, 2018

[4] Munteanu, R., Scoicaru, L.O., Militaru, M., Gagniuc, E., Micsa, C., Togoe, D., Vitalaru, B.A., Rusu, M.I., Tautan, M., Chiricuta, B., Udrea, M.V., Sonea, Al., Grigorescu, C.E.A., Birtoiu, I.A., Comparison of benign and malignant mammary tumors in dogs through Raman spectroscopy: Two clinical cases, In: Agrolife Scientific Journal, Bucharest, 2017

[5] Thornhill, J.A., Peritoneal dialysis in the dog and cat: an update, In: Compend Cortin Educ Prac Vet, 1981, 3, 20-34

[6] Viţălaru, B.A., Petrescu, V.F., Peritoneal Dialysis in Chronic Renal Failure on Cat, In: Scientific Works. Series C., Veterinary Medicine, Bucharest, 2016

[7] Costea, R., Vitalaru, B.A., Propofol induction anesthesia for central venous catheterization in dogs with renal failure, Journal of Biotechnology, 2015

[8] Vițălaru, B.A., Micşa, C., Peritoneal Dialysis in Acute Renal and Liver Failure, In: Agriculture and Agricultural Science Procedia, 2015, 6C, 392-396

[9] Ferche, O., Moldoveanu, A., Cinteza, D., Toader, C., Moldoveanu, F., Voinea, A., Taslitchi, C., From neuromotor command to feedback: A survey of techniques for rehabilitation through altered perception, In: 2015 E-Health and Bioengineering Conference (EHB), IEEE, 2015, 1-4

[10] Moldoveanu, A., Ferche, O.M., Moldoveanu, F., Lupu, R.G., Cinteză, D., Irimia, D.C., Toader, C., The TRAVEE system for a multimodal neuromotor rehabilitation, In: IEEE Access, 2019, 7, 8151-8171

[11] Özmen, Ö., Sârbu, R., Săseanu, A.S., Toader, C., The European Foundation for quality management (EFQM) excellence model in a in a low voltage switchgear company, In: The Amfiteatru Economic journal, 2017, 19, S11, 1064-1064

Authors:

\section{BOGDAN ALEXANDRU VIŢĂLARU1 ${ }^{1}$, RAZVAN SCARLAT²}

${ }^{1}$ University of Agricultural Sciences and Veterinary Medicine Bucharest, Faculty of Veterinary Medicine Bucharest, Department of Clinical Sciences, 105 Splaiul Independenței, Bucharest, Romania

${ }^{2}$ National Research \& Development Institute for Textiles and Leather, 16 Lucretiu Patrascanu street, 030508 Bucharest, Romania e-mail: office@incdtp.ro

Corresponding author:

BOGDAN ALEXANDRU VIȚĂLARU

e-mail: alexandrumv@yahoo.com 